УДК 78.147-057.87:502/504

(C) 2015

Боголюбов В. М., доктор педагогічних наук

Національний університет біоресурсів і природокористування України

\title{
СИСТЕМА ПРИНЦИПІВ СТАЛОГО РОЗВИТКУ ЯК ТЕОРЕТИЧНА ОСНОВА ПІДГОТОВКИ МАЙБУТНІХ ЕКОЛОГІВ
}

\section{Рецензент - доктор сільськогосподарських наук П. В. Писаренко}

У статті проаналізовано головні принциии сталого розвитку в контексті професійної підготовки майбутніх екологів. 3 метою формування професійної компетентності магістра-еколога акцентовано увагу на впровадженні в навчальний проиес предметних компетенцій. Такі компетениії розроблені на основі компетентнісно-діяльнісного підходу $i$ з урахуванням вимог Галузевих стандартів вищої освіти України. По кожній дисиипліні освітньо-професійної програми виділені ключові і професійні компетенції у контексті вирішення проблем переходу до сталого розвитку і принципів збалансованого природокористування.

Ключові слова: професійна підготовка екологів, освіта, принципи $і$ стратегія сталого розвитку.

Постановка проблеми. Після ухвалення «Порядку денного на XXI століття» [13] формування стратегії переходу суспільства до сталого розвитку відбувається досить бурхливо, опубліковано тисячі наукових статей і не один десяток підручників і посібників. Незважаючи на це, сталий розвиток досі сприймається широкою громадськістю як певна «утопія», оскільки не має, за словами В. Вовка, чітких, науково-обгрунтованих критеріальних меж, що дає змогу довільно визначати шляхи та засоби наближення до кінцевої мети [4].

У зв'язку з цим важливо приділити особливу увагу головним підходам у визначенні й обгрунтуванні критеріїв та показників сталого розвитку, а також у розробленні стандартів якості життєдіяльності населення за умов техногеннообтяжених регіонів України.

Аналіз останніх досліджень і публікацій, у яких започатковано розв'язання проблеми. У центрі концепції сталого розвитку - збереження людини як біологічного виду та прогресивний розвиток іiі як особистості. Фізіологічні й особистісні групи життєво важливих потреб, що забезпечують умовно бескінечне підтримання існування людського суспільства, поєднуються словом «соціальні». Загальновизнано, що соціальні проблеми можуть задовольнятись за умов достатнього рівня матеріального благополуччя людей, коли задовольняються основні потреби в житлі, їжі, питній воді, одязі, засобах гігієни, контакту 3 природою тощо.

Низка вчених, особливо економістів, небезпідставно вважають роль економічної складової сталого розвитку надзвичайно важливою у формуванні шляхів переходу до сталого розвитку. На наш погляд, роль соціальної складової у формуванні стратегії переходу суспільства до сталого розвитку не менш значуща. Економічна складова має вирішальне значення лише для країн 3 дуже низьким рівнем економічного розвитку. Урядам цих країн потрібно робити акценти на збалансованому використанні природних ресурсів.

За сучасних умов посилення техногенного навантаження дуже рідко збільшує «...можливість впровадження ресурсоощадних та екологобезпечних технологій» і забезпечує «...підвищення загальної екологічної грамотності населення...» [5]. Деякі вчені вважають, що «...сталість економічного розвитку - це здатність економічних систем зберігати стабільно збалансоване зростання...» [14]. Таке тлумачення сталого розвитку вступає у протиріччя з самою ідеєю заміни кількісного економічного зростання сталим (якісним) соціально-економічним розвитком [10].

Виходячи 3 сучасних трактувань виразу «sustainable development», «...сталий розвиток сільських територій можна охарактеризувати як рівномірне нарощування позитивних соціальних показників у повній відповідності з економічним та екологічним розвитком ...» [1]. Аналіз специфіки становлення нового екологічного знання за результатами досліджень Н. Бібік, С. Дорогунцова, М. Кисельова, Г. Пустовіта, О. Ральчука, Н. Рідей, А. Толстоухова та інших $[6,8,9,11]$ дало змогу розробити новий навчальний зміст екологічної освіти майбутніх екологів у аграрних ВНЗ. 3 метою формування професійної компетентності магістра-еколога акцентовано увагу на впровадженні в навчальний процес предметних компетенцій, розроблених на основі компетентнісно-діяльнісного підходу і з урахуванням вимог ГСВО, а також проявів у кожній дисципліні ключових і професійних компетенцій у кон- 


\section{СІЛЬСЬКЕ ГОСПОДАРСТВО. РОСЛИННИЦТВО}

тексті формування сталого (збалансованого) природокористування.

Таким чином, виходячи з основних принципів забезпечення переходу суспільства до сталого розвитку, можна сформулювати наступні вимоги до професійних компетенцій майбутніх фахівців в освітній галузі сталого розвитку:

- вміти оцінювати вплив антропогенних факторів на функціонування системи «суспільствоприрода»;

- мати навички формування і опрацювання баз статистичних даних;

- володіти методами математичного моделювання для обгрунтування заходів для гармонізації соціальної, економічної і екологічної підсистем;

- вміти розраховувати основні індикатори сталого розвитку;

- вміти спілкуватись 3 місцевими громадами щодо пріоритизації соціальних, економічних та екологічних проблем;

- вміти пояснювати широкій громадськості сутність головних принципів переходу суспільства до сталого розвитку;

- вміти передбачати ситуаційні зміни в системі «суспільство - природа».

Метою дослідження визначено розкриття сутності головних принципів переходу суспільства до сталого розвитку в контексті професійної підготовки майбутніх екологів, а головним завданням - деталізація предметних компетенцій у програмі підготовки майбутніх екологів зі врахуванням вимог Стратегії СЕК ООН освіти для сталого розвитку.

Результати дослідження. На основі вищезазначеного можна систематизувати найважливіші моменти, які утворюють проблематику сталого розвитку. Розробку стратегії сталого розвитку суспільства рекомендується базувати на загальнонаукових законах і методології економічних, соціальних, природничих та екологічних наук [2]. Водночас поряд із загальнонауковими методами досліджень використовуються і специфічні методи аналізу, прогнозування і управління станом системи «суспільство - природа». На основі оцінки впливу природних та антропогенних факторів повинні виявлятись закономірності функціонування системи «суспільство - природа», розроблятись та вдосконалюватись методологія i методи оцінювання іï стану та формуватись напрями розвитку цієї системи.

Для вивчення процесів розвитку соціальної, економічної та екологічної складових системи «суспільство - природа» використовують різноманітні методи здобування первинної та вторин- ної інформації. Первинну інформацію отримують на основі проведення прямих соціологічних, економічних та екологічних досліджень і опрацьовують методами математичної статистики [3, 12]. Методи отримання вторинної інформації полягають, як правило, у формуванні, обробці й опрацюванні державних і регіональних баз статистичних даних (економічних, соціальних, природно-ресурсних тощо) з використанням географічних інформаційних систем і технологій.

Щоб оцінювати і прогнозувати зміни стану соціальної, економічної і екологічної підсистем застосовують методи аналогій (систему оцінюють відповідно до моделі типової системи), емпіричного узагальнення (на підставі вивчення зв'язків між системами), моделювання (побудова фізичних, математичних та статистичних моделей). Слід зважати на те, що дані, отримані у процесі вивчення соціальної, економічної та екологічної систем, дають змогу характеризувати як їх стан і найважливіші процеси, що тривають у системах, так і тенденції розвитку цих процесів. На основі отриманих результатів можна прогнозувати розвиток цих систем, передбачати їх кризовий стан, а отже, планувати науково обгрунтовані заходи для створення умов збалансованого розвитку соціальної, економічної і екологічної підсистем та гарантувати безпечні умови життєдіяльності людини $[3,7]$.

Надзвичайно важливим етапом у формуванні стратегії сталого розвитку є обгрунтування переліку та змісту показників (індикаторів), які характеризують стан соціальної, економічної й екологічної складових системи «суспільство-природа» та визначення оціночних інтегрованих показників сталого розвитку на рівні населених пунктів, регіонів і країн.

3 урахуванням причинно-наслідкових зв'язків генеральною метою стратегії сталого розвитку $є$ збереження людства, а генеральним завданням збереження умов, за яких може існувати і розвиватися людство, тобто збереження біосфери та локальних екосистем [2].

Головне завдання стратегії сталого розвитку полягає у забезпеченні умов розвитку соціальної, економічної та екологічної складових системи «суспільство - природа». До завдань формування шляхів переходу до сталого розвитку можна віднести:

- дослідження розвитку соціально-економічної та екологічної підсистем;

- оцінювання стану соціально-економічної й екологічної підсистем;

- дослідження ролі інформаційних факторів в управлінні процесами переходу до сталого роз- 
витку;

- розроблення концепцій і стратегій сталого розвитку територій і країн;

- розроблення планів місцевих дій з охорони довкілля;

- обгрунтування управлінських рішень для цілеспрямованої трансформації соціальної, економічної й екологічної підсистем;

- районування територій i регіонів за рівнем розвитку соціальних підсистем.

Необхідною (хоча й далеко не достатньою) умовою переходу суспільства до сталого розвитку є дотримання п'яти головних принципів сталого розвитку [2]:

- Принцип сталого споживання і виробництва. Необхідно погодити стан життя тих, хто користується надмірними засобами (грошовими і матеріальними), 3 екологічними можливостями планети, зокрема відносне використання енергії і матеріальних ресурсів - принцип самообмеження споживання і виробництва [13]. Розміри і темпи зростання кількості населення повинні бути узгоджені з виробничим потенціалом глобальної екосистеми Землі, що змінюється. Необхідно задовольнити елементарні потреби всіх людей i всім надати можливість реалізувати свої прагнення до більш благополучного життя. Без цього сталий і довготривалий розвиток просто неможливий.

- Принцип екологізації економіки. Перегляд економічної та секторальної політики 3 метою «інтерналізації екстерналій» - трансформування зовнішніх екологічних i соціальних факторів, пов'язаних 3 виснаженням природних ресурсів $\mathrm{i}$ забрудненням довкілля, у внутрішні витрати виробництва та їх інтеграцію у процес ринкового ціноутворення. Законодавче забезпечення інноваційної еколого-економічної політики включає «торгівлю квотами на викиди», «еко-трудову податкову реформу», розвиток «органічного сектора» тощо [4].

- Принцип екоресурсної ємності біосфери. Обмеження, які існують у галузі експлуатації природних ресурсів, хоча і відносні, але абсолютно реальні. Вони пов'язані, у першу чергу, із обмеженою здатністю біосфери до самовідновлення, а також із сучасним рівнем техніки і соціальної організації.

- Принцип ентропійного ресурсопотоку. Ентропійний ресурсопотік речовини/енергії $€$ більш фундаментальним, ніж кругообіг обмінних вар- тостей [4].

Ніяка економіка принципово не може існувати без ентропійного потоку (економіка без кругообігу обмінних вартостей - це економіка натурального господарства).

Таким чином, економічна діяльність фундаментально залежить від наявності джерел вхідної низькоентропійної речовини/енергіï, які $\epsilon$ двох видів. Перші пов'язані з сучасним перетворенням потоку сонячної енергіï, а другі пов'язані 3 корисними копалинами Землі. Перші є відновлювальними і невичерпними ресурсами, другі не відновлювальними та вичерпними.

- Принцип коеволюції. Коеволюційний розвиток суспільства і природи полягає у симетричній еволюції людських систем (цінності, знання, культура, технології і артефакти) та природних систем 3 їх постійною взаємодією, а також взаємним впливом і адаптацією до змін у обох світах [2]. Люди не звільнені від коеволюційного процесу, що підносить одні види та скорочує інші. Згідно 3 «парадигмами коеволюції» спроможність людства до адаптації буде завжди критично важливою. А це вимагає здійснення екологобезпечної політики для збереження біологічного і ландшафтного різноманіття.

Висновок. Враховуючи головні принципи сталого розвитку, визначено вимоги до ключових компетенцій фахівців в освітній галузі сталого розвитку:

- знання методів оцінювання впливу природних та антропогенних факторів на функціонування системи «суспільство - природа» і навички формування і опрацювання баз статистичних даних (економічних, соціальних, природноресурсних тощо) 3 використанням сучасних інформаційних технологій;

- знання методів і вміння розраховувати основні показники (індикатори) сталого розвитку, вміння спілкуватись 3 представниками місцевих громад щодо пріоритизації існуючих соціальних, економічних та екологічних проблем і навички щодо розробки програм місцевих дій з охорони довкілля в контексті переходу суспільства до сталого розвитку;

- здатність до адаптації за умов соціальноекономічних та екологічних змін, вміння передбачати і активно опановувати ситуаційні зміни в системі «суспільство - природа» через цілеспрямовану трансформацію соціальної, економічної та екологічної підсистем. 


\section{БІБЛІОГРАФІЯ}

1. Баутин В. М. Устойчивое развитие сельских территорий: сущность, термины и понятия / В. М. Баутин, В. В. Козлов // Агрожурнал Московского государственного агроинженерного университета. - 2006. - №4 [Электронный ресурс]. Режим доступа : http://agromagazine.msau.ru/ index. php/-4/46-2008-03-20-13-001/106lr.html.

2. Стратегія сталого розвитку : підручник / [Боголюбов В. М., Клименко М. О., Мельник Л. Г., Прилипко В. А., Клименко Л. В.] ; за ред. В. М. Боголюбова. - Херсон : Грінь Д. С., 2012. $444 \mathrm{c}$.

3. Боголюбов В. М. Науково-методичний посібник 3 використання математико-статистичних методів при підготовці курсових і дипломних робіт студентами напряму 6.040106 «Екологія, охорона навколишнього середовища та збалансоване природокористування» / В. М. Боголюбов, В. А. Гайченко, О. В. Колесніченко. - К. : ЦП «КОМПРИНТ», 2015. - $101 \mathrm{c}$.

4. Вовк B. I. Курс «Екологічна економіка» (Ecological Economics), прочитаний у НаУКМА / В. I. Вовк. - Українська асоціація «Римського клубу» [Електронний ресурс]. - Режим доступу : http://clubofrome.org.ua).

5. Гоголь Т. В. Економічний механізм сталого розвитку сільських територій : всеукр. наукововиробничий журнал / Т. В. Гоголь // Сталий розвиток економіки. - С. 15-19 [Електронний ресурс]. - Режим доступу : http://www.nbuv.gov.ua/ portal/soc_gum/sre /20101/15.pdf.

6. Дорогунцов C. Сталий розвиток - цивілізаційний діалог природи і культури / С. Дорогунцов, О. Ральчук // Вісник НАНУ. - 2001. - №10. C. 17.

7. Моделювання і прогнозування стану довкілля : підручник / [Лаврик В. І., Боголюбов В. М.,
Полетаєва Л. М., Юрасов С. М., Ільїна В. Г.] ; за ред. В. І. Лаврика. - К. : ВЦ «Академія», 2010. $400 \mathrm{c}$.

8. Киселев Н. Н. Экологическая компонента в образовании XXI века : монография / Н. Н. Киселев // Наука и образование: современные трансформации. - Ин-т философии им. Г. С. Сковороды НАН Украины. - К. : ЦАРАПАН, 2008. - 305 с.

9. Компетнтнісний підхід у сучасній освіті: світовий досвід та українські перспективи: бібліотека з освітньої політики : кол. монографія / [Бібік Н. М., Ващенко Л. С., Локшина О. І. та ін.] ; за ред. О. В. Овчарук. - К.І.С., 2004. - 112 с.

10. Краткая история охраны природы за последние 30 лет [Электронный ресурс]. - Режим доступа : http://ecology-portal.ru/publ/osnovyobschey-ekologii/500253-kratkaya-istoriya-oxranyprirody-za-poslednie-30-let.html.

11. Програма дій «Порядок денний на 21 століття» / [пер. 3 англ. ВГО «Україна. Порядок денний на 21 століття»]. - К. : Інтелсфера, 2000. $-360 \mathrm{c}$.

12. Piдей H. М. Європейський простір вищої освіти в новому десятилітті: передумови і напрямки розвитку в Україні / Н. М. Рідей, Ю. В. Рибалко, Т. Ф. Хітренко // тематичний випуск «Вища освіта України у контексті інтеграції до європейського освітнього простору». - К., 2010. - С. 440-453.

13. Сидоренко E. B. Методы математической обработки в психологии / Е.В.Сидоренко. СПб. : ООО «Речь», 2007. - Глава 4. - 350 с. [Электронный ресурс]. - Режим доступа : www.labirint.ru/authors/52838/.

14. Шубравська О. Сталий економічний розвиток: поняття і напрями досліджень / О. Шубравська // Економіка України. - 2005. - №1. C. 36-42. 